\title{
Wiedeński okres w życiu Adolfa Hitlera w ujęciu Brigitte Hamann i Augusta Kubizka
}

Od ponad 70 lat nie słabnie, lecz przeciwnie - wciąż nasila się, zainteresowanie Adolfem Hitlerem - jego drogą życiową, czynami, aktywnością polityczną czy światopoglądem — zarówno wśród badaczy nazizmu, jak i innych osób starających się zgłębić fenomen przywódcy NSDAP i III Rzeszy. Jak by nie oceniać Hitlera i spierać się o niego, był on przecież postacią złowieszczą, a przy tym frapującą, choćby ze względu na ogrom zbrodni popełnionych $\mathrm{w}$ jego imieniu i na jego polecenie. Był zapewne jednym z tych polityków, którzy zasadniczo wpłynęli i to - rzecz oczywista — w sposób negatywny (obok m.in. Józefa Stalina) na dzieje XX w. Można by w związku z tym odwołać się do koncepcji wiktoriańskiego myśliciela — pisarza Thomasa Carlyle'a, dotyczącej roli wybitnych jednostek (bohaterów) w dziejach ludzkości, pamiętając wszakże o pejoratywnym znaczeniu tej teorii w odniesieniu do Führera ${ }^{1}$. W coraz bardziej obfitej literaturze na jego temat, nie tylko zresztą o charakterze stricte naukowym, lecz także publicystycznym i beletrystycznym, można dostrzec pasmo nieustannych inspiracji badawczych odwołujących się do jego rozległej działalności czy koncepcji politycznych. Warto zaznaczyć, że współcześnie hasło „Adolf Hitler” wywołuje gigantyczną liczbę ponad $6,5 \mathrm{mln}$ wystąpień w Internecie. Oczywiście są one - jak to w sieci — różnej objętości i wartości merytorycznej. Niewątpliwie świadczą jednak o nieprzemijającej „modzie” na Hitlera i wszystko, co się z nim w taki czy inny sposób kojarzy. Możliwość lektury liczących już setki tysięcy, jeśli nie miliony opracowań na ten temat upoważnia do wyrażenia opinii, że mniej więcej co kilkanaście lat pojawia się kolejna fala (Hitler-Welle) wzmożonej aktywności naukowej i edytorskiej — głównie w RFN — dotyczącej wodza narodowych socjalistów od 1921 r. i Niemiec w latach 1933-1945.

1 T. Carlyle, On Heros, Hero-Worship and the Heroic in History, London 1841, wyd. polskie b.m.w. 1891. 
Po raz pierwszy owo szczególne zainteresowanie przywódcą narodowych socjalistów i w ogóle nazizmem wystąpiło wyraźnie pod koniec lat 60. ubiegłego wieku i w następnej dekadzie tamtego stulecia. To właśnie wtedy głośne w świecie naukowym na Zachodzie stały się nazwiska takich autorów niemieckich, jak Martin Broszat, Georg Franz-Willing, Eberhard Jäckel, Hans-Adolf Jacobsen, Werner Jochmann czy Werner Maser ${ }^{2}$. W latach 80. i częściowo 90. XX w. naukowe dyskusje nie tylko w RFN zdominował spór historyków o wyjątkowość zbrodni nazistowskich (Historiker-Streit), zainicjowany przez Ernsta Noltego. Zachodnioniemieckie dywagacje na ten temat odbiły się szerokim echem m.in. w polskiej literaturze naukowej i publicystycznej ${ }^{3}$.

Jedna z kolejnych fal badań problematyki dotyczącej Hitlera i hitleryzmu żeby użyć tego już raczej zdezaktualizowanego określenia narodowego socjalizmu — niemal z hukiem przetacza się aktualnie przez Niemcy. Wydarzeniem o trudnym do przecenienia $w$ tej dziedzinie znaczeniu stało się opublikowanie w RFN w 2016 r. przez Institut für Zeitgeschichte w Monachium — po raz pierwszy po II wojnie światowej - dzieła Hitlera, będącego swego rodzaju biblią nazizmu, czyli Mein Kampf $f^{4}$. Wydanie w niewielkim nakładzie tej fundamentalnej księgi narodowego socjalizmu zbiegło się w czasie z wygaśnięciem praw do niej władz krajowych Bawarii. Pierwsza oficjalna po 1945 r. edycja Mein Kampf w Niemczech została opatrzona obszernym i krytycznym komentarzem oraz przypisami do tekstu. Mimo to znalazło się w RFN grono polityków i uczonych (m.in. Wolfgang Benz), w tym tamtejsza społeczność żydowska, wyrażających się negatywnie o wydawniczej inicjatywie Institut für Zeitgeschichte - jako niepotrzebnej, a nawet szkodliwej popularyzacji dzieła Hitlera. Jak mi wiadomo, nowa edycja Mein Kampf wzbudziła spore zainteresowanie w Niemczech, mimo niewielkiego nakładu.

Skoro jednak mowa o nieustannie przewijającej się w literaturze naukowej na całym świecie kwestii fenomenu Führera, to należy jeszcze wspomnieć o pojawiających się od czasu do czasu nowych biografiach Hitlera. W okresie tzw. Polski Ludowej w zasadzie jedyną dostępną w naszym kraju biografią tego polityka było, cenne zresztą, dzieło brytyjskiego historyka Alana Bullocka. Po formalnym

2 Także w tamtym okresie intensyfikacji uległy badania nad nazizmem prowadzone w Polsce, by wymienić takich autorów, jak Franciszek Ryszka, Karol Jonca, Czesław Pilichowski, Alfred Konieczny, Franciszek Połomski, Henryk Olszewski i wielu innych. Nieprzypadkowo od 1974 r. nieprzerwanie do pierwszej dekady XXI w., a zatem przez ponad 30 lat, ukazywała się we Wrocławiu (w ramach „Acta Universitatis Wratislaviensis”) stworzona przez K. Joncę unikalna w skali światowej seria wydawnicza „Studia nad Faszyzmem i Zbrodniami Hitlerowskimi”.

3 Szerzej o tym pisałem w artykule Historiografia narodowego socjalizmu w Republice Federalnej Niemiec. Główne wątki badawcze, „Studia nad Faszyzmem i Zbrodniami Hitlerowskimi” 20, 1997, s. 315 n.

${ }^{4}$ Hitler, Mein Kampf. Eine kritische Edition, red. Ch. Hartmann et al., t. 1-2, München 2016. W Polsce niepełny przekład tego dzieła ukazał się na początku lat 90 . XX w., lecz został wycofany z księgarń — jako propagujący, zakazany prawem w naszym kraju, narodowy socjalizm. 
upadku w Polsce ustroju komunistycznego zaczęło na rodzimym rynku księgarskim przybywać coraz więcej tego rodzaju, z reguły wartościowych, opracowań, by wymienić trzytomowe dzieło Iana Kershawa z początku XXI w. oraz świeżą (wydaną w 2015 r.), całkiem udaną, biografię autorstwa Volkera Ullricha ${ }^{5}$. Warto przypomnieć, że w ostatnim okresie zostały w naszym kraju wydane również opracowania dotyczące innych niż Hitler prominentów III Rzeszy. Wśród nich znalazły się opasłe dzieła o Josephie Goebbelsie i Heinrichu Himmlerze ${ }^{6}$. Należy jeszcze wspomnieć o dwóch innych inicjatywach wydawniczych, a mianowicie o edycji w Polsce trzytomowych dzienników Goebbelsa oraz o zupełnie niedawno (w 2016 r.) opublikowanych wspomnieniach z lat 1934-1944 czołowego ideologa nazistowskiego Alfreda Rosenberga.

Mimo niemalże wylewu w ostatnich latach w Polsce, a zwłaszcza za granicą, literatury dotyczącej Hitlera i w ogóle nazizmu w Niemczech nie zostało do tej pory napisane na ten temat ostatnie słowo. Co więcej, w rzeczonej materii badawczej nadal występują tzw. białe plamy. Należy jednak zauważyć, że są one stopniowo usuwane w kolejnych publikacjach naukowych. Do stosunkowo najsłabiej dotychczas opracowanych zagadnień w odniesieniu do samego Hitlera wciąż należą — jak ostatnio trafnie wskazał Marek Kornat ${ }^{7}$ — kwestie dotyczące jego młodości w Linzu i Wiedniu oraz jego udziału w I wojnie światowej. Znacznie bardziej pod tym względem kompleksowa, choć także niepełna, jest aktualna wiedza o Hitlerze w późniejszych okresach jego publicznej aktywności, czyli w czasach Republiki Weimarskiej i III Rzeszy.

W związku z tym nasuwa się ogólne spostrzeżenie odnośnie do literatury naukowej o Führerze. O ile mianowicie dość dokładnie i wnikliwie zbadano już okres działalności Hitlera po objęciu przez niego urzędu kanclerza Rzeszy w 1933 r., w tym lata II wojny światowej, o tyle jeszcze nie wszystko zostało spenetrowane i ustalone na temat jego aktywności oraz poglądów politycznych, zwłaszcza na samym początku lat 20. XX w., gdy dopiero budował swój wizerunek przywódcy, a organizacje nazistowskie znajdowały się w powijakach. Co prawda białych plam w badaniach nad wczesnymi latami politycznej działalności Hitlera w Monachium (do 1923 r.) jest o wiele mniej niż w odniesieniu do okresu sprzed 1918/1919 r., ale i tak wciąż daleko do pełnego zgłębienia tej problematyki. Tylko w ostatnich kilkunastu latach zostały bowiem odkryte nowe źródła archiwalne i pojawiły się nieznane przedtem informacje uzupełniające i korygujące

5 I. Kershaw, Hitler, t. 1. 1889-1936. Hybris, t. 2. 1936-1941. Nemezis, t. 3. 1941-1945. Nemezis, Poznań 2001-2003; V. Ullrich, Hitler. Narodziny zła 1889-1939, Warszawa 2015. Należy jeszcze odnotować biografie Hitlera autorstwa Joachima Festa (Warszawa 1995) i Marlis Steinert (Wrocław 2001). Ponadto w okresie III Rzeczypospolitej drukiem ukazało się w Polsce dwutomowe dzieło A. Bullocka, Hitler i Stalin. Żywoty równoległe, Warszawa 1994.

${ }^{6}$ Autorem obu publikacji jest Peter Longerich, noszą one tytuły: Goebbels. Apostoł diabła (Warszawa 2014) oraz Himmler. Buchalter śmierci (Warszawa 2014).

7 M. Kornat, August Kubizek (1888-1956) i jego wspomnienia, [w:] A. Kubizek, Adolf Hitler. Mój przyjaciel z młodości, Czerwonak 2014, s. 7-8. 
wiedzę o ówczesnym Führerze nazistów ${ }^{8}$. Na samym początku lat 20 . ubiegłego stulecia wcale nie było jeszcze pewne, że za ok. 10 lat będzie on jednym z najbardziej wpływowych polityków niemieckich w tamtym okresie, że sięgnie po urząd kanclerza Rzeszy, a za kolejne 10 lat stanie się władcą znacznej części Europy. Można zatem stwierdzić, że znajomość wczesnego etapu w kształtowaniu się politycznej kariery Hitlera staje się coraz bardziej kompleksowa.

Jak już wzmiankowałem, najwięcej niejasności i wątpliwości poznawczych rodzi jednak młodość przyszłego wodza NSDAP i III Rzeszy, czyli pierwsze 30 lat jego życia (1889-1918). Związane one były najpierw z jego domem rodzinnym w Braunau am Inn, następnie z pobytem w Linzu oraz Wiedniu i Monachium (1904-1913), później zaś z udziałem w działaniach militarnych na frontach wojennych. Jeszcze kilkanaście lat temu czytelnicy w Polsce, interesujący się fenomenem Hitlera, dysponowali o wiele mniejszą wiedzą na ten temat niż obecnie. Dzięki kilku niedawno wydanym w naszym kraju książkom zyskali oni jednak możliwość jej znacznego poszerzenia. Mam na myśli zwłaszcza dwukrotnie opublikowane w Polsce dzieło cenionej austriackiej badaczki Brigitte Hamann o dojrzewaniu Hitlera w Wiedniu do roli wodza nazistów i innych Niemców ${ }^{9}$. Na omówienie zasługują także, już powołane przeze mnie w przypisie, wspomnienia jego przyjaciela ze wspólnego pobytu w Linzu i stolicy monarchii habsburskiej (1905-1908) - Augusta Kubizka. Osobno należy wskazać cenną rozprawę niemieckiego historyka Thomasa Webera o Hitlerze z czasów I wojny światowej ${ }^{10}$. $\mathrm{W}$ tym artykule recenzyjnym odniosę się do treści tylko dwóch pierwszych z wymienionych opracowań, gdyż zgodnie ze swym tytułem dotyczy on okresu w życiu przyszłego Führera do 1913 r. Choć i monografia Hamann, i książka Kubizka przedstawiają żywot Hitlera sprzed wybuchu I wojny światowej, są więc pokrewne tematycznie, a nawet poniekąd uzupełniające się, to jednak należy uznać je za opracowania zasadniczo różniące się od siebie. Pierwsza z nich jest bowiem typową monografią naukową, napisaną przez współczesną autorkę, osobiście nigdy

${ }^{8}$ Niektóre z nich (jak np. stosunek Hitlera do Bawarskiej Republiki Rad w 1919 r. czy jego kontakty ze środowiskami żydowskimi w Monachium) starałem się wykorzystać w monografii $\mathrm{Od}$ piwiarnianego klubu do organizacji wywrotowej. Nazizm w latach 1919-1924, Torun 2005.

9 B. Hamann, Wiedeń Hitlera. Lata nauki pewnego dyktatora, Warszawa 2013. Książka ta po raz pierwszy (nie w całości) ukazała się drukiem w Polsce w 1999 r., wcześniej została wydana po niemiecku (1996) i angielsku (1999). Warto także wspomnieć o książce Floriana Illiesa, 1913. Rok przed burza (Warszawa 2014), w której znajdują się wzmianki o pobycie Hitlera w Monachium przed wybuchem I wojny światowej, upływającym mu zwłaszcza na malowaniu akwareli lokalnych budowli (zob. s. 152-153).

10 T. Weber, Pierwsza wojna Hitlera. Adolf Hitler, żolnierz putku Lista i pierwsza wojna światowa, Poznań 2011. Tego okresu w życiu Hitlera dotyczy też kontrowersyjna książka Davida Lewisa, Człowiek, który stworzyt Hitlera (Warszawa 2005), w której przedstawiona została rzekomo szczególna rola znanego w świecie medycznym neuropsychiatry Edmunda Forstera w ukształtowaniu osobowości przyszłego przywódcy NSDAP i III Rzeszy. Forster leczył Hitlera pod koniec I wojny światowej w szpitalu w Pasłęku, dokąd trafił on z objawami ślepoty, wywołanymi działaniem gazów bojowych. 
nieznającą Hitlera i czerpiącą wiedzę o nim z rozmaitych źródeł oraz literatury; druga zaś stanowi wspomnienia osoby, której zadaniem wcale nie było stworzenie tego rodzaju rozprawy, jaka wyszła spod pióra austriackiej uczonej czy innych badaczy profesjonalnie zajmujących się analizą politycznej działalności i poglądów Hitlera. Warto zaznaczyć, że Hamann wielokrotnie odwołuje się do książki Kubizka, odnosząc się do niej jako do raczej wiarygodnego źródła. Wydaje się nawet wobec jej autora dość bezkrytyczna.

Celem Kubizka było przybliżenie potencjalnym czytelnikom owych wspomnień takiego Hitlera, jakiego zapamiętał, a może tylko chciał zapamiętać z czasów swojej i jego młodości. W przeciwieństwie do Hamann bynajmniej nie dążył on do obiektywizacji swych wywodów, lecz świadomie przedstawił — niekiedy mijając się z faktami lub nieco konfabulując — dość subiektywny obraz Hitlera (dosłownie „widzianego” oczami Kubizka) w okresie sprzed wybuchu I wojny światowej. Do kwestii raczej wątpliwych, choć nie bezwartościowych, a nawet ciekawych walorów poznawczych wspomnień Kubizka nawiążę jeszcze w dalszej części tego artykułu. W tym miejscu powtórzę jednak za M. Kornatem, że relacja tego przyjaciela Hitlera - za takiego Kubizek się bowiem uważał - a w rzeczywistości tylko jego dobrego znajomego, gdyż przyszły Führer w zasadzie nie był (nie tylko podczas pobytu w Wiedniu) zdolny do przyjaźni, stanowi „niezastąpiony w swym rodzaju tekst świadka historii"11. Już choćby z tego względu nie powinno się jej pomijać w naukowych zabiegach o odtworzenie wczesnej drogi życiowej Hitlera. Co więcej, koniecznie należy do celów naukowych wykorzystywać wspomnienia Kubizka, zwłaszcza że stanowią one jedno z bardzo nielicznych bezpośrednich świadectw w tej dziedzinie ${ }^{12}$.

Warto zaznaczyć, że zaledwie kilka osób znających Hitlera z wiedeńskiego okresu jego życia zdecydowało się opublikować swoje wspomnienia o nim, gdy był on już wodzem nazistów i kanclerzem Rzeszy, czy też już po jego śmierci w kwaterze w Berlinie w 1945 r. Dobrze się więc stało, że niedawno w Polsce wydano wreszcie - po kilkudziesięciu latach od pierwodruku — opracowanie Kubizka. Dzięki temu pojawiła się na naszym rynku księgarskim druga książka wspomnieniowa o Hitlerze. W 2005 r. opublikowane zostały bowiem „zeznania” jego sekretarki z lat 1933-1945 - Christy Schroeder ${ }^{13}$. Z niemałym zainteresowaniem polskich czytelników spotkała się również w 2015 r. publikacja autorstwa osobistego, „nadwornego” fotografa Hitlera - Heinricha Hoffmanna. Jak Kubizek, tak

11 M. Kornat, op. cit., s. 29.

12 Prócz Kubizka wspomnienia o Hitlerze z jego wiedeńskiego okresu życia wydało jeszcze kilku innych jego ówczesnych znajomych: Josef Greiner (Das Ende des Hitler-Mythos, Wien 1947), Reinhold Hanisch (I was Hitler's Buddy, ,The New Republic” 1939, s. 23 n., Franz Jetzinger (Hitlers Jugend, Wien 1956). Warto dodać, że B. Hamann (op. cit., s. 9 n.) przeprowadziła wywiady z członkami rodzin osób, które — jak Rudolf Jahoda czy Rudolf Häusler — były znajomymi Hitlera podczas jego pobytu w Wiedniu.

13 [Ch. Schroeder], Zeznania sekretarki. 12 lat u boku Hitlera 1933-1945, thum. A. Wróblewski, Warszawa 2005. 
i Hoffmann uważał się za przyjaciela Hitlera ${ }^{14}$. Z przyszłym wodzem III Rzeszy związał się jeszcze przed objęciem przez niego urzędu niemieckiego kanclerza, stając się jego powiernikiem, a nawet swatem. To Hoffmann przedstawił bowiem Hitlerowi swoją asystentkę Ewę Braun, która ostatecznie została żoną Führera. Należy ponadto odnotować wydanie w $2015 \mathrm{r}$. w Polsce jeszcze jednych wspomnień dotyczących Hitlera, a mianowicie książki jego kierowcy — Ericha Kempki ${ }^{15}$.

Lektura wspomnień Kubizka stanie się bardziej interesująca, a nawet pouczająca, jeśli zostanie poprzedzona sięgnięciem po rzeczoną książkę Hamann. Naukową monografię austriackiej badaczki można bowiem uznać za swego rodzaju wprowadzenie do jego rozważań na temat Hitlera. Ukazuje ona historyczne podłoże, rozmaite przesłanki i uwarunkowania aktywności Hitlera - niewielkiej zresztą w porównaniu z jego działalnością po $1918 \mathrm{r}$. — w stolicy monarchii habsburskiej przed I wojną światową. Austriacka autorka niewątpliwie czyni to z szerszej perspektywy poznawczej niż Kubizek.

Zaopatrzona w aparaturę naukową i niezbędny dystans do „bohatera” swoich wywodów prezentuje w swej - merytorycznie i warsztatowo bardzo dobrej - książce nie tylko samego Hitlera, lecz także inne postaci z życia publicznego Wiednia w schyłkowym okresie cesarstwa Habsburgów, a równocześnie końca fin de siècle. Metropolia ta nie jest zatem w narracji Hamann jedynie Wiedniem Hitlera, jak głosi tytuł omawianej publikacji, choć zapewne właśnie w Wiedniu upłynęły ważne dla przyszłego Führera „lata nauki”. Stolica upadającego imperium została przez nią przedstawiona jako mozaika - na ogół przeciwstawnych, a nawet wrogich sobie - rozmaitych sił społecznych, politycznych i narodowościowych oraz tendencji kulturalnych czy prądów literackich. Wiedeń początków XX w. nie był dla Hitlera — według Hamann — tym samym miastem, jakie było utożsamiane wówczas z takimi wybitnymi postaciami, jak Sigmund Freud, Gustav Mahler, Arthur Schnitzler czy Ludwig Wittgenstein. Przeciwnie - stolica monarchii habsburskiej widziana oczami młodego Hitlera to „Wiedeń maluczkich, nierozumiejących wiedeńskiego modernizmu, odrzucających go jako zdegenerowany, za mało rodzimy, zbyt internacjonalistyczny, żydowski i wolnomyślicielski" ${ }^{\prime 6}$. Można się zgodzić z austriacką badaczką, że przyszły wódz nazistów postrzegał ową metropolię jako skupisko imigrantów, nieudaczników, mieszkańców noclegowni dla mężczyzn, a przy tym „,zęsto ludzi zalęknionych, podatnych na najróżniejsze obskuranckie teorie, przede wszystkim te, które dawały im - mimo całej nędzy — poczucie, że w rzeczywistości są jednak elitą, kimś lepszym"17. Niemal wyłącznie w takim bowiem środowisku Hitler obracał się przed I wojną światową.

${ }^{14}$ H. Hoffmann, Mój przyjaciel Hitler. Wspomnienia fotografa Hitlera, Warszawa 2015.

15 E. Kempka, Byłem kierowca Hitlera, Czerwonak 2015.

16 B. Hamann, op. cit., s. 7. Odsyłam także do mojego artykułu O przesłankach i źródłach światopoglądu Adolfa Hitlera, "Studia nad Autorytaryzmem i Totalitaryzmem” 35, 2013, nr 2, s. $105 \mathrm{n}$.

${ }^{17}$ B. Hamann, op. cit., s. 7. 
Był po prostu jednym z jego, dość zresztą licznych, przedstawicieli i nikim więcej, podobnie jak jego kompan w tamtym okresie - August Kubizek.

Wskazane w przytoczonym cytacie z książki Hamann nieuzasadnione poczucie wyższości (nie tylko w przypadku Hitlera) wynikało u owych — według jej określenia — „życiowych nieudaczników” ni mniej, ni więcej tylko z przynależności do - uważającego się za lepszy od innych nacji — narodu niemieckiego. Przypomnę, że Wiedeń przed upadkiem monarchii Habsburgów stanowił tygiel wielu narodowości — poczynając od austriackich Niemców, poprzez Słowian (w tym wielu Polaków), a na licznej społeczności żydowskiej kończąc. Wywody Hamann potwierdzają wyrażoną już dawno przez A. Bullocka tezę, że przyszły Führer podczas pobytu w tym mieście przesiąknął przepojoną prymitywizmem, niechęcią do tzw. obcych i nacjonalizmem, „filozofią domów noclegowych" 18 . To właśnie ona $\mathrm{w}$ znacznym stopniu ukształtowała $\mathrm{w}$ późniejszych latach jego ideologię, która opierała się - jak wiadomo - m.in. na antyliberalizmie, antyarystokratyzmie, antykapitalizmie, antyslawizmie, antysemityzmie i rasizmie.

Można z dużym prawdopodobieństwem przyjąć, że przynajmniej niektóre z komponentów swego światopoglądu Hitler zaczerpnął z lektury ukazujących się na początku XX w. w stolicy Austro-Węgier czasopism, takich jak „Alldeutsches Tagblatt”, „Deutsche Volksblatt”, „Ostdeutsche Rundschau” czy „Ostara-Hefte”. Wszystkie reprezentowały rozwijającą się od schyłku XIX w. ideologię volkistowską, czyli myśl antysemicko-rasistowską i antymodernistyczną. W poszukiwaniu odpowiedzi na pytanie o ideowe inspiracje Hitlera w tamtym okresie Hamann słusznie zwróciła uwagę na wymienione periodyki. Przyszły wódz narodowych socjalistów i w ogóle Niemców mógł — choć wcale nie musiał - jeszcze podczas pobytu w Wiedniu zapoznać się z poglądami takich volkistowskich publicystów, jak Guido von List, Lanz von Liebenfels czy Otto Weininger ${ }^{19}$. Wiele wskazuje na to, że właśnie tak było. Większy jednak niż wymienieni autorzy wpływ na Hitlera mogli wywrzeć dwaj wiedeńscy politycy — Karl Lueger i Georg Ritter von Schönerer. Warto dodać, że sam Hitler uznał w Mein Kampf obu z nich za swoich nauczycieli, a nawet mistrzów, sprzed I wojny światowej ${ }^{20}$. Według austriackiej badaczki Hitler miał cenić Luegera — burmistrza stolicy monarchii habsburskiej, zmarłego w 1910 r. — za zdolności oratorskie i osiągnięcia organizacyjne. W Schönererze upatrywał natomiast niekwestionowanego i utalentowanego przywódcy austriackiej organizacji wszechniemieckiej (Alldeutscher Verband). Można przyjąć, że jej polityczny program był szczególnie bliski Hitlerowi jeszcze przed 1914 r. W każdym razie mógł się on wiele nauczyć od tych dwóch polityków. Jeśli wierzyć słowom Hitlera z okresu jego pobytu w więzieniu po nieudanym puczu monachijskim (1923 r.), a wydają się one raczej szczere:

18 A. Bullock, Hitler. Studium tyranii, Warszawa 1975, s. 64.

19 Nie będę szerzej analizował tej kwestii, gdyż szczegółowo piszę o tym w artykule $O$ przesłankach $i$ źródtach...

${ }^{20}$ A. Hitler, Mein Kampf, München 1933, s. 156, passim. 
„Wiedeń był i pozostaje dla mnie najcięższą, aczkolwiek także najgruntowniejszą szkołą w moim życiu. Otrzymałem tam podstawy światopoglądu w ogóle oraz pozyskałem sposób politycznego rozpatrywania spraw w szczególności”21.

Jakie jeszcze publikacje lub działalność jakich innych osób mogły wtedy lec u podstaw przyszłych koncepcji politycznych Hitlera? — wciąż trudno jednoznacznie stwierdzić. Nawet tak wytrawna uczona jak Hamann nie była w stanie precyzyjnie i przekonująco wypowiedzieć się na ten temat. Niewątpliwie łatwiej pokusić się o udzielenie odpowiedzi na pytanie, jaka literatura w ogóle ukształtowała Hitlera jako przywódcę nazistów i III Rzeszy, choć również w tej kwestii pojawia się wiele spekulacji. W opracowaniach naukowych przyjęło się, częściowo za samym Hitlerem, wymieniać w tym kontekście - niejako jednym tchem - opracowania m.in. Ottona Bismarcka, Gustawa Le Bona, Houstona Stewarta Chamberlaina, Heinricha Classa, Arthura de Gobineau, Henryka Ibsena, Karola Maya, Fryderyka Nietzschego, Heinricha von Treitschkego i Emila Zoli22.

Warto nadmienić, że kilka lat temu próby ustalenia zestawu lektur Hitlera podjął się amerykański badacz Timothy W. Ryback. W odróżnieniu od innych autorów analizie nie poddał on pośrednich, pochodzących z „drugiej ręki” informacji na ten temat, lecz zestaw publikacji, które znajdowały się w prywatnej bibliotece Hitlera jako kanclerza III Rzeszy ${ }^{23}$. Z jego ustaleń wynika, że Führer miał w swych zbiorach rozprawy Henry'ego Forda o Żydach, rasisty Paula de Lagarde'a, teoretyka wojskowości Carla von Clausewitza oraz przepowiednie Nostradamusa, a także Pismo Święte, Don Kichota, Przygody Robinsona Crusoe, Podróże Guliwera i Chatę wuja Toma. Dobór prawdopodobnych lektur Hitlera był więc raczej dość przypadkowy. Niewątpliwie jednak zawartość tego księgozbioru niemało mówi o zainteresowaniach jego właściciela. Nie można wszakże jednoznacznie stwierdzić, w jakim stopniu wymienione dzieła ukształtowały światopogląd wodza nazistów i III Rzeszy. Nie sposób bowiem ustalić, czy rzeczywiście Hitler spędzał czas na lekturze wyżej wskazanych publikacji, czy jedynie znajdowały się one w zasięgu jego ręki. Dość pobieżne i wyrywkowe informacje na ten temat zostały zawarte już w Mein Kampf. Wynika z nich, że przyszły dyktator Niemiec lubił w ogóle czytać, szczególnie nie przebierając wśród publikacji,

21 Ibidem, s. 124

22 Zob. m.in. K.D. Bracher, Die deutsche Diktatur. Entstehung, Struktur, Folgen des Nationalsozialismus, Köln-Berlin 1970, s. 96, passim; H. Grebing, Der Nationalsozialismus. Ursprung und Wesen, München 1959, s. 23, passim; W. Maser, Adolf Hitler. Legende, Mythos, Wirklichkeit, München 1973, s. 176 n.; H. Olszewski, Nauka historii w upadku. Studium o historiografii i ideologii historycznej w imperialistycznych Niemczech, Warszawa-Poznań 1982, s. 214.

${ }^{23}$ Po II wojnie światowej została ona - jako ocalała z pożogi $1945 \mathrm{r}$. — w części przewieziona do USA. Wyniki swych dociekań T.W. Ryback przedstawił w wydanej także w Polsce książce Prywatna biblioteka Hitlera. Książki, które go uksztaltowaty (Warszawa 2000). Warto jeszcze wspomnieć o publikacji Stana Lauryssensa, Człowiek, który wymyślit Trzecia Rzeszę (Wrocław 2000), w której został ukazany wpływ konserwatywnego pisarza Arthura Moellera van den Brucka na poglądy Hitlera na początku lat 20. XX w. 
po które sięgał $\mathrm{w}$ wolnych chwilach. Nie pozostaje zatem nic innego prócz spekulacji dotyczących zestawu jego lektur. Należy jednak zauważyć, że dla wyjaśnienia fenomenu Hitlera problem ideowych inspiracji jego politycznych poglądów stanowi niebagatelną kwestię poznawczą ${ }^{24}$. Rzecz sprowadza się bowiem do udzielenia odpowiedzi na pytanie, na ile doktryna polityczna Hitlera odznaczała się oryginalnością, a w jakim stopniu stanowiła konglomerat zapatrywań innych osób, przetworzonych przez niego samego w konkretnych celach politycznych. Zdaje się nie ulegać wątpliwości, że był mało nowatorski i w ogóle nietwórczy w swych koncepcjach odnoszących się np. do spraw ustrojowych, narodowych czy żydowskich. Na ten temat panuje niemal absolutna zgodność opinii w literaturze naukowej.

Po tej dygresji, mającej wszakże wyraźny związek z problematyką niniejszego artykułu, należy wrócić do omawiania książki Hamann. Jak wynika nie tylko z wywodów tej autorki, Hitler podczas pobytu w Wiedniu niczym szczególnym nie wyróżniał się spośród zwykłych mieszkańców metropolii. Mało tego: znalazł się w grupie, dość zresztą pokaźnej, bardziej nieudolnych i pasywnych spośród lokatorów wspomnianych noclegowni. $\mathrm{Z}$ niemałym trudem utrzymywał się przy życiu dzięki malowaniu obrazów (z reguły pejzaży lub budowli), nie mając odpowiednich kwalifikacji (brak matury), by osiągnąć wymarzony cel podjęcia studiów w dziedzinie architektury. W tym miejscu dodam, że tych informacji akurat jednoznacznie nie potwierdza w swych wspomnieniach Kubizek. Dlaczego nie uwypuklił on właśnie tego charakterystycznego wątku w życiu Hitlera w Wiedniu — o tym będzie jeszcze mowa. Wspomniałem już, że na początku minionego stulecia, a nawet jeszcze niedługo po zakończeniu I wojny światowej, w zasadzie nic nie wskazywało na późniejszą karierę polityczną Hitlera. Hamann nie odmawia mu jednak w czasach wiedeńskich pewnego zmysłu, a nawet talentu obserwacji rzeczywistości społeczno-politycznej, który zresztą przydawał mu się w całym jego życiu. W opinii austriackiej autorki Hitler wcale nie zamierzał wtedy zostać politykiem, lecz właśnie utalentowanym architektem lub w ogóle uznanym artystą. Z tego względu chętnie uczestniczył — jeśli tylko dysponował odpowiednimi środkami finansowymi, a nieczęsto się to zdarzało ${ }^{25}$ — w spektaklach operowych, uczęszczał do filharmonii lub zwiedzał muzea. Należy zaznaczyć, że niejedną informację na temat upodobań młodego Hitlera, a zwłaszcza te wskazujące na jego duszę niespełnionego artysty, potwierdza lektura wspomnień Kubizka. Nierzadko

24 Już po objęciu przez nazistów władzy w Niemczech wyraźnie ujawniła się wśród propagandystów III Rzeszy tendencja do umniejszania wpływu cudzych poglądów na ideologię Hitlera i w ogóle narodowego socjalizmu. Zob. m.in. E. Unger, Das Schrifttum des Nationalsozialismus von 1919 bis zum 1. Januar 1934, Berlin 1934.

25 Według Waltera Görlitza (Adolf Hitler, Göttingen-Berlin 1960, s. 19) Hitler żył w Wiedniu „W zupełnej nędzy”. Inaczej zapatruje się na ten problem F. Ryszka (Noc i mgła. Niemcy w okresie hitlerowskim, Wrocław 1966, s. 13), według którego Hitler dysponował wtedy rentą sierocą po matce w wysokości 50 tys. koron, co równało się rocznym zarobkom siedmiu robotników w monarchii habsburskiej, a więc nie było małą kwotą. 
właśnie wspólnie z Kubizkiem — wielkim miłośnikiem muzyki, teatru i ogólnie sztuki - Hitler wybierał się do opery czy na różne koncerty. Wyprzedzając tok dalszych wywodów: Kubizek odnotował w swych wspomnieniach niemal uwielbienie swego przyjaciela do muzyki, zwłaszcza dla patetycznych, przepojonych tzw. niemieckością dzieł Ryszarda Wagnera ${ }^{26}$. Pozbawionych tych cech utworów muzycznych Hitler po prostu nie lubił, a nawet nie rozumiał i starał się raczej nie słuchać. Zamiłowanie do muzyki niewątpliwie bardzo zbliżyło Kubizka do Hitlera, stając się jednym z fundamentów ich znajomości w Wiedniu. Warto w związku z tym przypomnieć, że przez pewien czas wspólnie zamieszkiwali oni tam w jednym wynajętym pokoju. Latem $1908 \mathrm{r}$. drogi mężczyzn rozeszły się aż na 30 lat. Ponownie Kubizek spotkał się z Hitlerem w Linzu w kwietniu 1938 r. po tzw. Anschlussie Austrii do Rzeszy ${ }^{27}$.

Skłonność do przebywania wśród rozmaitych muz, w otoczeniu których Hitler czuł się znakomicie, bynajmniej nie oznaczała braku z jego strony zainteresowania sprawami politycznymi przed wybuchem I wojny światowej. Przeciwnie - ciągnęło go do nich chyba w nie mniejszym stopniu niż do świata artystycznego. Hamann przekonująco opisuje w swej książce wcale nierzadkie przypadki przysłuchiwania się przez niego obradom parlamentu (Rady Państwa) w Wiedniu, udziału w zebraniach niektórych tamtejszych partii politycznych (głównie o profilu nacjonalistycznym) i studiowania miejscowej prasy. Z omawianych przez badaczkę źródeł wynika, że Hitler krytycznie odnosił się jeszcze przed 1918 r. do dynastii Habsburgów, zarzucając jej nieudolność w rządzeniu i niedostateczną dbałość o interesy austriackich Niemców ${ }^{28}$. Choć Hitler podczas swego pobytu w Wiedniu był właściwie nikim i na pewno nie ujawnił jeszcze zdolności krasomówczych czy agitatorskich, a tym bardziej cech dyktatora i zbrodniarza, którym stał się w okresie III Rzeszy, to nie sposób jednak wyjaśnić jego późniejszych (od lat 30. XX w.) sukcesów politycznych i ostatecznej klęski w 1945 r. bez znajomości warunków i okoliczności wpływających na jego życie w czasach młodości, czyli nie tylko w okresie wiedeńskim, lecz jeszcze przed przybyciem do stolicy Austro-Węgier z Linzu. Z taką tezą Hamann należy się w pełni zgodzić. Autorka omawianej monografii dość jednak pobieżnie zajęła się losami Hitlera przed 1906 r., zamieszczając jedynie krótki rozdział na ten temat. Można ją tłumaczyć tym, że w zasadzie nie wniosłaby swymi wywodami o pobycie przyszłego Führera w Linzu wiele oryginalnych ustaleń w porównaniu z informacjami zawartymi we wspomnianych biografiach Bullocka, Kershawa

26 A. Kubizek, op. cit., s. 56, passim.

27 J.C. Fest, Hitler. Eine Biographie, Frankfurt am Main-Wien 1973, s. 1017. Hitler zaproponował wtedy Kubizkowi funkcję dyrektora jednej z orkiestr, lecz ten jej nie przyjął. Po raz ostatni dwaj dawni przyjaciele spotkali się na festiwalu wagnerowskim w Bayreuth w 1940 r. Dopiero dwa lata później Kubizek wstąpił do NSDAP. Z powodu bliskiej znajomości z Hitlerem przebywał po II wojnie światowej przez 16 miesięcy w amerykańskim więzieniu. Zob. M. Kornat, op. cit., s. 15.

28 B. Hamann, op. cit., 135, passim. 
czy Ullricha, a także we wspomnieniach Kubizka. Niewątpliwie właśnie w Wiedniu, a nie już w Linzu Hitler stawiał pierwsze, jeszcze nieporadne kroki na drodze do swojej przyszłej kariery politycznej. Rację ma Hamann, gdy twierdzi, że zróżnicowana, przesiąknięta niemałą tolerancyjnością duchowa atmosfera stolicy Austro-Węgier, z jej mnogością tendencji, nastrojów i prądów intelektualnych na początku XX w., nadającą tej metropolii niepowtarzalnego charakteru estetyczno-obyczajowego, nie mogła pozostać bez wpływu na postawy jej mieszkańców, zarówno tych wywodzących się z wyższych warstw, jak i osób pokroju Hitlera, należących do marginesu społecznego. Wszystko to okazało się okolicznościami i czynnikami sprzyjającymi jego dojrzewaniu do aktywności politycznej. Można zatem przyjąć, że okres pobytu Hitlera w Wiedniu był rzeczywiście „latami nauki" przyszłego dyktatora Niemiec i pogromcy Europy, jak utrzymuje autorka omawianej książki. Nie należy jednak przesadzać w przywiązywaniu szczególnej wagi do tego etapu w życiu przyszłego kanclerza.

W przekonaniu Hamann to właśnie w stolicy monarchii habsburskiej ukształtowały się zwłaszcza zręby antysemityzmu Hitlera, który stał się od 1933 r. nader konsekwentnie realizowanym przez niego składnikiem jego światopoglądu. Przyszły Führer nie manifestował wszakże już przed I wojną światową niemal zoologicznej nienawiści do Żydów, jak czynił to później, choć w Wiedniu na ogół okazywał im swoją wyższość i nierzadko również pogardę. Jak pisał w Mein Kampf, raził go niechlujny wygląd biednych i niezasymilowanych Żydów w tym mieście („,cudaki z długimi pejsami”). Nader krytycznie odnosił się także do samej religii mojżeszowej. Hitler potrafił się jednak w tamtym okresie nawet częściowo zaprzyjaźnić z jednym z reprezentantów tej nacji - Josefem Naumannem ${ }^{29}$. Również Kubizek nie wskazuje wyraźnie we wspomnieniach o swym przyjacielu na jego zdecydowanie antysemicką postawę w pierwszej dekadzie XX w. Jeśli już pojawiają się w nich Żydzi, to przede wszystkim jako negatywnie oceniany przez Hitlera element narodowościowej mozaiki Wiednia. Jeszcze nie występują oni jako „odwieczni wrogowie” rasy germańskiej, jakimi staną się w propagandzie NSDAP od początku lat 20. ubiegłego stulecia. Wobec Żydów miało w latach 1905-1908 kierować Hitlerem nic więcej prócz zwykłej niechęci połączonej niekiedy z uczuciem obrzydzenia do nich. $Z$ takim negatywnym, a na pewno krytycznym, lecz jeszcze nie chorobliwie nienawistnym nastawieniem do tej nacji przyszły Führer przybył — zdaniem Kubizka — do Wiednia już z Linzu. Według niego niechęć do Żydów cechowała wtedy nie tylko Hitlera, ale też wielu innych, ubogich niemieckich mieszkańców stolicy monarchii habsburskiej. Kubizek akcentuje natomiast występujące już podczas pobytu w Wiedniu przywiązanie przyszłego wodza nazistów i III Rzeszy do niemieckich wartości narodowych (marzenie o wielkości Rzeszy i jej potędze w Europie), choć wprost nie nazywa tego

29 Ibidem, s. 212, passim. Odsyłam też do prac Francisa L. Carstena, Faschismus in Österreich. Von Schönerer zu Hitler (München 1977) i Petera G.J. Pulzera, Die Entstehung des politischen Antisemitismus in Deutschland und Österreich 1868-1914 (Gütersloh 1966). 
nacjonalizmem ${ }^{30}$. Już wtedy pragnął on widzieć Austro-Węgry — oczyszczone — w ramach jednego państwa niemieckiego.

Z wywodów Kubizka wyłania się obraz Hitlera jako człowieka o raczej silnym charakterze i niepospolitej osobowości, nastawionego na osiągniecie zamierzonych celów i dość konsekwentnie poszukującego swojego miejsca w realiach habsburskiej metropolii, a przy tym osoby nieco zagubionej, zamkniętej w sobie oraz skłonnej do melancholii, odprawiania egzorcyzmów i okultyzmu. Wszystkie te i inne opisane przez Kubizka cechy Hitlera jeszcze bardziej nasiliły się w późniejszym okresie jego życia. Pozostając pod niemałym urokiem swego przyjaciela, a nawet częściowo podziwiając go, czego zresztą nie kryje w swych wspomnieniach, Kubizek szczególnie nie uwypukla — być może właśnie z tych powodów - rozmaitych słabości i licznych problemów Hitlera, z jakimi borykał się on w codziennej egzystencji. Jeśli już pisze o przeciwnościach losu, z którymi przyszło zmierzyć się wtedy jego przyjacielowi, czyni to głównie po to, aby wykazać, że na ogół potrafił uporać się z różnymi trudnościami. Kubizek nie jest jednak zupełnie bezkrytyczny wobec swego kompana z czasów wiedeńskich. $\mathrm{Z}$ omawianych wspomnień wynika, że nawet częściowo raził go brak empatii u Hitlera i jego nadmierna podejrzliwość wobec obcych. Zwraca też uwagę na częstą u Hitlera zmienność nastrojów, łączącą się z popadaniem przez niego albo w stan swego rodzaju ekstazy, albo przejściowego otępienia ${ }^{31}$. Dla raczej prostolinijnego Kubizka, podchodzącego do życia dość optymistycznie, a nawet radośnie, Hitler okazywał się człowiekiem nie tylko niestabilnym psychicznie, lecz także raczej ponurym i tajemniczym. W każdym razie był on już przed I wojną światową postacią niejednoznaczną i wewnętrznie zagmatwaną, a równocześnie nietuzinkową.

Warto zaznaczyć, że to w znacznej mierze za sprawą relacji Kubizka taki wizerunek Hitlera dość powszechnie przyjął się w literaturze naukowej. Można się z nim zapoznać niemal w każdej dotyczącej go biografii powstałej kilkanaście lat po II wojnie światowej. Za raczej wiarygodne źródło wiedzy o młodym Hitlerze uważa - spośród współczesnych autorów rozpraw o wodzu III Rzeszy — wspomnienia Kubizka zwłaszcza Kershaw ${ }^{32}$. Należy jednak pamiętać, że zostały one po raz pierwszy wydane ponad 40 lat (1953 r.) po zakończeniu osobistej znajomości z Hitlerem w Linzu i Wiedniu (1908 r.). Niejeden fakt, okoliczność czy ocena mogły się przecież zatrzeć lub zniekształcić w pamięci Kubizka. Mimo to pisze on we wstępie do swej książki, że nie zamierza ,niczego upiększać, ale również i przemilczać", lecz ukazać Hitlera zgodnie z prawdą ${ }^{33}$. Nie wydaje się jednak,

30 Zob. też W. Maser, Hitler i Stalin. Fałszerstwo, wymyst, prawda, Wrocław 2010, s. 111.

31 Częściowo na podstawie wspomnień Kubizka tak oto Joachim C. Fest (Hitler, t. 1. Droga do władzy, Warszawa 1995, s. 49) wyraził się o Hitlerze z czasów wiedeńskich: „Skłócony z całym światem, czuł nienawiść do wszystkiego, z czym się zetknął”. Zob. też idem, Das Gesicht des Dritten Reiches. Profile einer totalitären Herrschaft, München 1963, s. 26.

32 I. Kershaw, Hitler, t. 1, s. 17.

33 A. Kubizek, op. cit., s. 36. 
by Kubizek mógł być po upływie tak wielu lat w pełni precyzyjny i obiektywny w swej relacji. Co więcej, zastrzega on, że pragnie przedstawić Hitlera takim, jakim był on rzeczywiście w latach 1905-1908, a nawet takim, jak gdyby nie przeżył I wojny światowej, nie zaś poprzez pryzmat jego późniejszej kariery politycznej. Niezupełnie jednak udała mu się tego rodzaju narracja. Trudno się zresztą temu dziwić. Prawdopodobnie nie powstałyby bowiem wspomnienia Kubizka o Hitlerze, gdyby nie stał się on jednym z najważniejszych polityków XX w. Czymś oczywistym wydaje się zatem dążenie do spojrzenia na niego z szerszej perspektywy czasowej niż tylko $\mathrm{z}$ lat sprzed $1914 \mathrm{r}$.

W końcowej części tego artykułu należy wskazać na okoliczności napisania przez Kubizka wspomnień o młodym Hitlerze. Trudno dokładnie ustalić, kiedy pojawił się w jego głowie zamysł spisania swej znajomości z przyszłym Führerem. Niemal na pewno nie powstał on jeszcze przed podjęciem przez Hitlera działalności w NSDAP, a nawet w ogóle w okresie walki tej partii o władzę w Niemczech. Najwcześniej Kubizek mógł — jak sądzę — myśleć o podzieleniu się z czytelnikami swymi wspomnieniami o Hitlerze dopiero wtedy, gdy ten został kanclerzem Rzeszy na początku 1933 r. Wiadomo, że Kubizek złożył mu z tego powodu gratulacje, a Hitler za nie podziękował ${ }^{34}$. Jak już wzmiankowałem, do pierwszego po wielu latach spotkania Kubizka z Hitlerem doszło dopiero w 1938 r. W tym samym roku Główne Archiwum NSDAP zwróciło się bowiem do niego z prośbą o napisanie relacji wspomnieniowej ze znajomości z młodym Hitlerem. Zamiarem władz nazistowskich było skłonienie Kubizka do ukazania Hitlera z czasów wiedeńskich jako osoby już wtedy predestynowanej do bycia wodzem „wielkiej Rzeszy"35. Kubizek nie podjął się jednak — z nieznanych przyczyn — tego zadania. Ponownie otrzymał takie zamówienie (na polecenie Martina Bormanna) już podczas II wojny światowej. Tym razem zgodził się na napisanie tekstu liczącego ok. 150 stron. Nigdy jednak nie został on opublikowany. Do końca istnienia III Rzeszy Kubizek nie uległ zresztą żadnym innym namowom do spisania swych wspomnień. Udało się to dopiero po 1945 r. badaczowi nazizmu Franzowi Jetzingerowi, który zamierzał przygotować biografię młodego Hitlera i potrzebował relacji naocznego świadka ${ }^{36}$. Warto dodać, że książka na ten temat ukazała się drukiem trzy lata po pierwszej edycji wspomnień Kubizka. Zostały one przekazane w 1951 r. do Leopold Stocker Verlag w Grazu. W porównaniu z tekstem przygotowanym w okresie III Rzeszy opublikowane w 1953 r. wspomnienia Kubizka stanowiły znacznie obszerniejszy tekst. Liczyły bowiem niemal 300 stron. Do 1975 r. miały miejsce aż cztery wydania tej książki. Już jej pierwsza edycja wzbudziła spore zainteresowanie czytelników w RFN. Do 2002 r. było w sumie siedem wydań tych wspomnień. Książka Kubizka została również przetłumaczona na język angielski i po raz pierwszy wydana w nim w 1955 r. Warto nadmienić,

34 M. Kornat, op. cit., s. 14.

35 Bundesarchiv Koblenz, Nachlass 26/17 a. Za: M. Kornat, op. cit., s. 16.

36 F. Jetzinger, Hitlers Jugend. Phantasien, Lügen - und die Wahrheit, Wien 1956. 
że na jej podstawie powstał w latach 70 . ubiegłego stulecia także scenariusz filmu telewizyjnego stacji ZDF i ORF, noszący w oryginale tytuł Ein junger Mann aus dem Innviertel. W 2014 r. przyszedł wreszcie czas na opublikowanie wspomnień Kubizka w Polsce przez oficynę wydawniczą Vesper. Dzięki temu przedsięwzięciu do rąk naszych czytelników trafiło opracowanie niewątpliwie zachęcające do jego lektury. Powinno ono zainteresować tych wszystkich, których wciąż frapuje fenomen Hitlera i którzy nie znaleźli jeszcze — mimo ogromu odnośnej literatury — ostatecznych odpowiedzi na dotyczące tego problemu liczne pytania.

\section{Bibliografia}

Bullock A., Hitler. Studium tyranii, Warszawa 1975.

Fest J.C., Hitler, t. 1. Droga do władzy, Warszawa 1995.

Hamann B., Wiedeń Hitlera. Lata nauki pewnego dyktatora, Warszawa 2013.

Hitler A., Mein Kampf, München 1933.

Kershaw I., Hitler, t. 1. 1889-1936. Hybris, Poznań 2001.

Kershaw I., Hitler, t. 2. 1836-1941. Nemezis, Poznań 2002.

Kershaw I., Hitler, t. 3. 1841-1945. Nemezis, Poznań 2003.

Kornat M., August Kubizek (1888-1956) i jego wspomnienia, [w:] A. Kubizek, Adolf Hitler. Mój przyjaciel z młodości, Czerwonak 2014.

Lewis D., Człowiek, który stworzył Hitlera, Warszawa 2005.

Maciejewski M., O przesłankach i źródłach światopogladu Adolfa Hitlera, „Studia nad Autorytaryzmem i Totalitaryzmem" 35, 2013, nr 2.

Maser W., Hitler i Stalin. Fatszerstwo, wymyst, prawda, Wrocław 2010.

Ryback T.W., Prywatna biblioteka Hitlera. Książki, które go uksztaltowaty, Warszawa 2000.

Weber T., Pierwsza wojna Hitlera. Adolf Hitler, żotnierz pulku Lista i pierwsza wojna światowa, Poznań 2011.

\section{THE VIENNESE PERIOD IN ADOLF HITLER'S LIFE AS PRESENTED BY BRIGITTE HAMANN AND AUGUST KUBIZEK}

\section{Summary}

The article discusses the literature and the findings concerning the relatively least explored questions concerning Adolf Hitler, namely those of his youth. As the author stresses, just over a decade ago Polish readers interested in the Hitler phenomenon knew much less than they do now. Thanks to several books recently published in Poland they have had a chance to considerably expand their knowledge. The present author points to two figures, Brigitte Hamann and August Kubizek, focusing on the similarities and differences in their approach to this period of Hitler's life.

Keywords: Brigitte Hamann, Adolf Hitler, August Kubizek, Vienna.

Marek Maciejewski

marek.maciejewski@uwr.edu.pl 